\title{
AN OSPREY NEST AT TORCH RIVER
}

by. Maurice G. Street, Nipawin

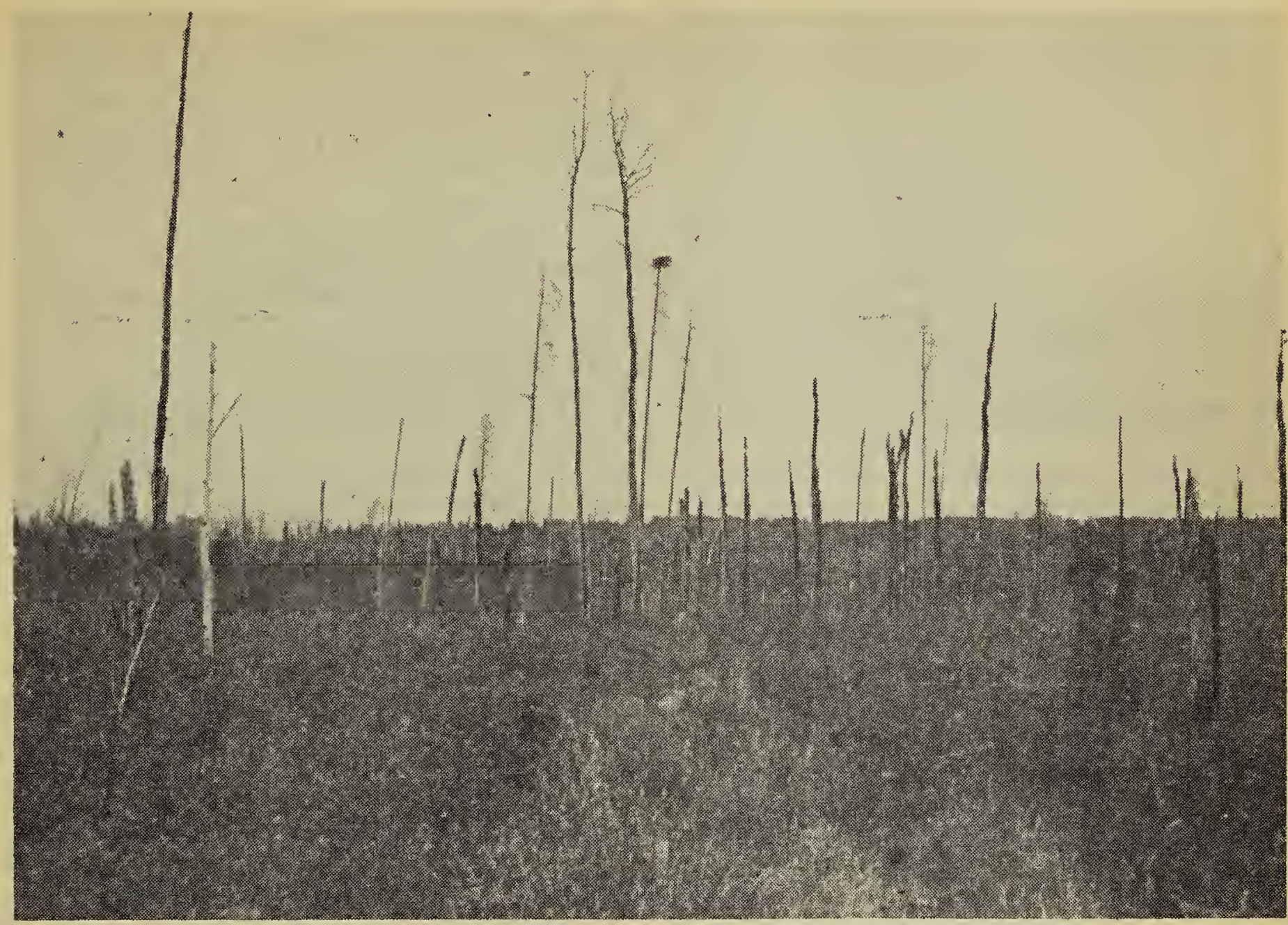

Photo by M. G. Street

Osprey nest at Torch Riyer, June 10, 1960.

On June 10, 1960, with Ann, Billy and Walter Matthews, I visited the nesting tree of a pair of Ospreys located on the SE $1 / 4$ 31-53-15 W2. This is aproximately 18 miles north and six miles west of Nipawin, and little over a mile southwest of C. Stuart Francis' Spruce Dale Farm at Torch River.

The nest tree is a dead jackpine, standing amid scattered dead trees and stubs on a burnt-over area on the south slope of the Torch River and about one-half mile from the river itself. The nest is placed at the extreme tip of the tree at an estimated 80 feet from the ground. The nest appears to be approximately four feet wide with a depth of three feet.

The female, a very dark bird, left the nest when we were 100 yards distant; then continually circled in the vicinity and several times alighted on the nest during the half hour we spent, there. The male meanwhile sat quietly some 150 yards away on another tall tree. No young could be seen from the ground, nor were there any droppings at the base of the tree. Therefore it seems probable that the nest contained eggs or very young birds.

During our observation of the Osprey's nest a pair of House Sparrows were seen to enter the base of the nest and the chirpings of the young sparrows could be clearly heard.

The food source of this pair of Ospreys is unknown. It seems unlikely they could take the required amount from the Torch River, as small fish appear to be scarce there. The nearest lake known to contain coarse fish is Falling Horse Lake, a small lake 30 air-line miles to the north.

This nest falls within the Nipawin district as defined in the Birds of the Saskatchewan River (C. S. Houston and M. G. Street, 1959). Therefore it is a new nesting record for the district, making a total of 132 species for which nests have been found-and 142 species breeding. 